\title{
STUDI KOMPUTASI METODE $A B$ INITIO DFT DALAM KAJIAN STRUKTURAL DAN SIFAT ELEKTRONIK SENYAWA KALSIUM BOROHIDRID-DIAMONIA SEBAGAI PENYIMPAN HIDROGEN
}

\author{
Muhammad Arsyik Kurniawan S. \\ Program Studi Kimia FMIPA Universitas Islam Indonesia \\ Jalan Kaliurang KM 14,5, Sleman, Yogyakarta, 55584 \\ E-mail:m.arsyik@gmail.com
}

\begin{abstract}
ABSTRAK
Telah dilakukan kajian teoritis tentang struktur dan sifat elektronik dari senyawa $\mathrm{Ca}\left(\mathrm{BH}_{4}\right)_{2} \cdot 2 \mathrm{NH}_{3}$ sebagai salah satu material yang berpotensi digunakan untuk menyimpan dan penghasil hidrogen melalui proses dehidrogenasi. Perhitungan teoritis energi, Density of States dan celah pita elektron dari struktur kompleks $\mathrm{Ca}\left(\mathrm{BH}_{4}\right)_{2} \cdot 2 \mathrm{NH}_{3}$ dilakukan dengan Density Functional Theory (DFT) dan fungsi energi perubahan dan korelasi menggunakan metode Generalized Gradient Approximation (GGA).

Berdasarkan analisis struktur dan sifat elektronik kristal kompleks $\mathrm{Ca}\left(\mathrm{BH}_{4}\right)_{2} \cdot 2 \mathrm{NH}_{3}$ diperoleh atom-atom hidrogen yang berpotensi sebagai sumber molekul hidrogen yaitu hidrogen $\left(\mathrm{H}^{\delta-}\right)$ dari $\mathrm{BH}_{4}$ dan hidrogen $\left(\mathrm{H}^{\delta+}\right)$ dari $\mathrm{NH}_{3}$ dalam bentuk ikatan dihidrogen $\mathrm{N}-$ $\mathrm{H} \cdots \mathrm{H}-\mathrm{B}$. Hasil perhitungan simulasi didapatkan besar celah energi band gap sebesar 5,68 $\mathrm{eV}$, yang menyatakan material ini sebagai insulator. Dari data analisis lebih lanjut terhadap studi pelepasan molekul $\mathrm{H}_{2}$ vs $\mathrm{NH}_{3}$ sebesar 2,30 eV vs $1,52 \mathrm{eV}$, mengindikasikan material $\mathrm{Ca}\left(\mathrm{BH}_{4}\right)_{2} \cdot 2 \mathrm{NH}_{3}$ lebih rendah untuk melepaskan molekul $\mathrm{H}_{2}$ dibanding $\mathrm{NH}_{3}$, data ini sesuai dengan hasil pengamatan eksperimen.
\end{abstract}

Kata kunci: penyimpan hidrogen, density functional theory, ikatan dihidrogen.

\begin{abstract}
Study of structure and electronic properties of solid $\mathrm{Ca}\left(\mathrm{BH}_{4}\right)_{2} \cdot 2 \mathrm{NH}_{3}$ as a hydrogen storage and production material has been performed. The energy, density of states, and band structure of solid $\mathrm{Ca}\left(\mathrm{BH}_{4}\right)_{2} \cdot 2 \mathrm{NH}_{3}$ have calculated within framework of density functional theory (DFT) and generalized gradient approximation (GGA) for the exchangecorrelation energy functional.

Structure analysis and electronic properties of $\mathrm{Ca}\left(\mathrm{BH}_{4}\right)_{2} \cdot 2 \mathrm{NH}_{3}$ indicated that the source of hydrogen molecule was verified by interaction from hydrogen $\left(\mathrm{H}^{\delta-}\right)$ from $\mathrm{BH}_{4}^{-}$ and hydrogen $\left(\mathrm{H}^{\delta+}\right)$ from $\mathrm{NH}_{3}$ in dihydrogen bonding site $\mathrm{B}-\mathrm{H} \cdots \mathrm{H}-\mathrm{N}$. The calculated band structures implied an indirect wide band gap of $5.68 \mathrm{eV}$, indicated that this material is insulator. The simulation result gets that removal energy of $\mathrm{H}_{2}$ vs $\mathrm{NH}_{3}$ is $1.52 \mathrm{eV}$ vs 2.30 $\mathrm{eV}$, indicated dissociation of $\mathrm{H}_{2}$ is less favorable than $\mathrm{NH}_{3}$ molecule, this theoritical study has a good agreement with experiment observation.
\end{abstract}

Keyword: hydrogen storage, density functional theory, dihydrogen bonding

Studi Komputasi Metode Ab Initio Dft Dalam Kajian Struktural dan Sifat Elektronik

Senyawa Kalsium Borohidrid-Diamonia Sebagai Penyimpan Hidrogen

(Muhammad Arsyik Kurniawan) 
Pendahuluan

Minyak bumi yang melimpah sebagian besar digunakan untuk memproduksi bensin atau bahan bakar lainnya, tingginya eksplorasi minyak bumi memungkinkan cadangan minyak bumi akan mencapai masa limit sekaligus meningkatnya pemanasan global akibat produksi karbon dioksida $\left(\mathrm{CO}_{2}\right)$ yang tinggi. Tuntutan energi global yang melonjak bersama - sama dengan meningkatnya kesadaran akan habisnya sumber daya bahan bakar fosil ini mendorong para peneliti maupun ilmuwan melakukan upaya pencarian sumber energi baru seperti hidrogen (Anonim, 2007).

Keuntungan lain dari gas hidrogen adalah keberadaannya yang melimpah di alam, serta kemungkinannya untuk digunakan dan diproduksi kembali (renewable), berbeda dengan bahan bakan hidrokarbon jenis minyak bumi yang sangat melimpah tetapi tidak bisa diproduksi kembali dalam waktu singkat (unrenewable) sehingga memungkinkan untuk habis (Irani, 2002).

Dalam konsep energi yang dapat diperbaharui (renewable energy), saat ini teknologi mengarah kepada pemanfaatan material zat padat yang digunakan sebagai bahan penyimpan gas hidrogen yang mudah diproduksi, diantaranya adalah molekul kompleks amonia boran
$\left(\mathrm{NH}_{3}-\mathrm{BH}_{3}\right)$ sebagai material penyimpan hidrogen (Baitalow et al., 2002) yang mampu menyimpan dan menghasilkan gas hidrogen melalui reaksi dehidrogenasi, senyawa amonia-boran $\left(\mathrm{NH}_{3} \cdot \mathrm{BH}_{3}\right)$ mengandung $19,6 \%$ hidrogen telah dipertimbangkan sebagai bahan yang menjanjikan sebagai material penyimpan hidrogen. Namun untuk melepaskan semua hidrogen dari amoniaboran membutuhkan suhu yang sangat tinggi sekitar $1000{ }^{\circ} \mathrm{C}$ (Frueh et al., 2011)

Perkembangan eksperimen telah dilakukan untuk meningkatkan kemampuan penyimpanan dan menghasilkan gas hidrogen yang lebih banyak dengan reaksi dehidrogenasi yang lebih baik, diantarannya dengan mereaksikan amonia-boran dengan hidrida logam alkali maupun alkali-tanah. Campuran amonia-boran dengan hidrida logam alkali yang telah dikembangkan seperti $\mathrm{Mg}\left(\mathrm{BH}_{4}\right)_{2} \cdot 2 \mathrm{NH}_{3}$ (Soloveichik et al., 2008), $\mathrm{Ca}\left(\mathrm{NH}_{2} \mathrm{BH}_{3}\right)_{2}-$ $\mathrm{NH}_{3}$ (Chua et al., 2009). Namun saat ini muncul masalah lainnya dimana kombinasi amonia-boran dengan hidrida logam justru menghasilkan pelepasan amonia $\left(\mathrm{NH}_{3}\right)$ daripada gas hidrogen $\left(\mathrm{H}_{2}\right)$ seperti yang dialami oleh $\mathrm{Chu}$ et al. (2010) pada senyawa $\mathrm{Ca}\left(\mathrm{BH}_{4}\right)_{2} \cdot 2 \mathrm{NH}_{3}$, hal ini sangat tidak diinginkan karena selain mempengaruhi efisiensi hasil $\mathrm{H}_{2}$ 
juga menyebabkan gas $\mathrm{H}_{2}$ yang

terkontaminasi amonia $\left(\mathrm{NH}_{3}\right)$.

Reaksi decomposisi senyawa

$\mathrm{Ca}\left(\mathrm{BH}_{4}\right)_{2} \cdot 2 \mathrm{NH}_{3}$ seperti pada persamaan reaksi dibawah ini,

Persamaan reaksi 1



Persamaan reaksi 2

$\mathrm{Ca}\left(\mathrm{BH}_{4}\right)_{2} \cdot 2 \mathrm{NH}_{3} \stackrel{190^{\circ} \mathrm{C}}{\longrightarrow} 1 / 4 \mathrm{Ca}\left(\mathrm{BH}_{4}\right)_{2}+1 / 4 \mathrm{Ca}_{3}\left(\mathrm{BN}_{2}\right)_{2}+\mathrm{BN}+6 \mathrm{H}_{2}$

Pada reaksi 1 dilakukan didalam sistem reaktor terbuka, sedangkan reaksi 2 pada sistem tertutup (closed vessel).

Pembahasan tentang tentang struktur dan sifat elektronik sangat dibutuhkan dalam memahami sifat decomposisi material dan juga untuk pengembangan studi lebih lanjut mengenai sifat penyimpan hidrogen. Pada artikel ini, kajian struktur dan sifat elektronik material $\mathrm{Ca}\left(\mathrm{BH}_{4}\right)_{2} \cdot 2 \mathrm{NH}_{3}$ dipelajari dengan menggunakan tehnik Projector Augmented-Wave (PAW) dari metode Density Functional Theory (DFT), sehingga diharapkan dari kajian ini memberikan gambaran dan pemahaman tentang ikatan dan sifat dekomposisi dari $\mathrm{Ca}\left(\mathrm{BH}_{4}\right)_{2} \cdot 2 \mathrm{NH}_{3}$.

\section{Tujuan Penelitian}

Penelitian ini dilakukan diantaranya bertujuan untuk hal-hal sebagai berikut :
1. Penggunaan tehnik Projector Augmented-Wave untuk pemodelan zat padat (solid state) dalam hal ini material $\mathrm{Ca}\left(\mathrm{BH}_{4}\right)_{2} \cdot 2 \mathrm{NH}_{3}$.

2. Mempelajari struktur dan sifat elektronik material $\mathrm{Ca}\left(\mathrm{BH}_{4}\right)_{2} \cdot 2 \mathrm{NH}_{3}$

\section{Metode Penelitian}

Perangkat Keras

Perangkat keras yang digunakan dalam penelitian ini menggunakan komputer dengan spesifikasi: CPU Processor Intel Core2Quad $2.66 \mathrm{GHz}$ dengan Physical Memory 4Gb, kapasitas Storage $200 \mathrm{~Gb}$, serta GPU.

\section{Perangkat Lunak}

Perangkat lunak atau Software yang digunakan diantaranya:

1) Program ABINIT, (Gonze et al. 2009), untuk perhitungan optimasi geometri.

2) Program AtomPAW, (Holzwarth et al. 2001), sebagai generator basis set

3) Program Vesta, (Momma and Izumi, 2011), digunakan untuk visualisasi struktur elektronik.

4) Program GnuPlot, digunakan untuk analisis dan ploting data statistik fungsi gelombang.

\section{Bahan Kajian}

Bahan kajian modeling struktur kristal $\mathrm{Ca}\left(\mathrm{BH}_{4}\right)_{2} \cdot 2 \mathrm{NH}_{3}$ diperoleh dari spektra

Studi Komputasi Metode Ab Initio Dft Dalam Kajian Struktural dan Sifat Elektronik Senyawa Kalsium Borohidrid-Diamonia Sebagai Penyimpan Hidrogen 
instrumen XRD dari publikasi eksperimen Chu et al. (2010).

\section{Rancangan Penelitian}

\section{Pembuatan Basis Set Plane-wave}

Basis set adalah representasi fungsi matematika yang digunakan sebagai deskriptor fungsi gelombang elektron untuk disertakan dalam perhitungan. Basis set yang digunakan adalah plane-wave Projector AugmentedWave (PAW) yang berbentuk persamaan

$$
\psi_{j . \mathrm{k}}(r)=\sum_{\mathrm{G}} c_{j, \mathrm{k}+\mathrm{G}} \cdot \mathrm{e}^{i(i+\mathrm{G}) \cdot \mathrm{r}}
$$

yang dikembangkan oleh Blöchl (1994), indeks $j$ merupakan indeks tiap elektron, koefisien $\mathrm{k}$ dipengaruhi oleh ukuran kisi nyata (real lattice) dan koefisien G dipengaruhi oleh ukuran kisi kebalikannya (reciprocal lattice). Secara garis besar basis set plane-wave bergantung pada ukuran kisi sistemnya

\section{Studi Konvergensi Energi Kinetik}

Basis set plane wave secara khusus diterapkan dalam pemodelan yang menggunakan tehnik pendekatan supercell untuk sistem yang tak terhingga jumlahnya seperti kisi kristal. Parameter khusus seperti energi kinetik cutoff yang digunakan sebagai pembatas jumlah plane wave yang akan digunakan. Seperti pada pers. (2) koefisien ekspansi $c_{j, \mathrm{k}+\mathrm{G}}$ dari pers. (1) akan berkurang secara eksponensial dengan meningkatnya energi kinetik dari fungsi plane wave,

$$
E_{k}=\frac{m v^{2}}{2} \cong \frac{(k-G)^{2}}{2} \leq E_{c u t} \quad \ldots . .
$$

Kualitas basis set plane wave hanya bergantung terhadap ukuran kisi dan nilai energi kinetik cutoff. Fungsi gelombang yang digunakan harus dapat menghitung nilai energi di setiap titik ruang didalam kisi kristal yang terintegrasi dalam zona Brillouin (Ashcroft dan Mermin, 1976), titik-titik dalam ruang kisi ini disebut $k$-point.

\section{Studi Struktur dan Elektronik kristal $\mathrm{Ca}\left(\mathrm{BH}_{4}\right)_{2} \cdot \mathbf{2} \mathrm{NH}_{3}$}

Metode DFT (Hohenberg dan Kohn, 1964) memperhitungkan bahwa energi sistem merupakan besaran kerapatan sistem sebagai nilai total dari kerapatan semua fungsi gelombang dalam sistem tersebut.

$$
E[\rho(r)]=E\left[\psi^{2}\right]
$$

Dengan pendekatan yang dikembangkan oleh Kohn dan Sham (1965), nilai minimum dari fungsi total energi merupakan energi GS (ground-state) sistem, maka kerapatan elektronik yang memiliki nilai minimum ini merupakan energi eksak keadaan dasar dari sistem. Persamaan energi total sistem merupakan jumlah dari energi potensial, kinetik dan energi interaksi pertukaran dan korelasi antar elektron. 


$$
E[\rho(r)]=\int V_{\text {:on }}(r) \rho(r) d r+T[\rho(r)]+E_{x c}[\rho(r)]
$$

Energi pertukaran dan korelasi (xc) dari suku ketiga pers 3 diatas menggunakan metode pendekatan gradien tergeneralisir (GGA) dari Perdew et al. (1996). Optimasi dilakukan dengan kondisi toleransi perbedaan gaya hingga mencapai $0,025 \mathrm{eV} / \AA ̊$ dan toleransi untuk konvergensi geometri tegangan kisi sebesar 0,05 GPa hingga didapatkan struktur terelaksasikan baik posisi atom, bentuk kisi dan volume kisi, kemudian kajian dilanjutkan dengan mempelajari bentuk struktur dan sifat elektronik dari kristal $\mathrm{Ca}\left(\mathrm{BH}_{4}\right)_{2} \cdot 2 \mathrm{NH}_{3}$.

\section{Pembahasan}

\section{Pembuatan Basis set Plane-Wave}

Dalam sistem zat padat dimana atom tidak bisa bergerak secara leluasa seperti pada fasa cair maupun gas, sehingga dapat diasumsikan bahwa dalam zat padat tidak semua elektron ikut serta dalam interaksi dengan atom lain karena sifat rigid sistem padat. Dalam penyusunan basis set fungsi gelombang elektron harus mempertimbangkan keterlibatan seluruh atau sebagian orbital dalam suatu atom untuk berinteraksi dengan atom lain dalam bentuk ikatan, seperti yang disajikan dalam Tabel 1. e. ISSN: 2503-2364

Tabel 1. Orbital core-valensi atom $\mathrm{Ca}$, B, $\mathbf{N}$ dan $\mathbf{H}$

\begin{tabular}{|c|c|c|c|}
\hline Atom & \multicolumn{3}{|c|}{ Orbital } \\
\hline \multirow[t]{2}{*}{ Kalsium } & \multicolumn{3}{|c|}{$(1 s)^{2}(2 s)^{2}(2 p)^{6}(3 s)^{2}(3 p)^{6}(3 \mathrm{~d})^{0}(4 s)^{2}$} \\
\hline & Core & $\longleftrightarrow \longleftarrow$ & Valensi \\
\hline \multirow[t]{2}{*}{ Boron } & \multicolumn{3}{|c|}{$(1 s)^{2}(2 s)^{2}(2 p)^{1}$} \\
\hline & Core & $\longleftarrow$ & Valensi \\
\hline \multirow[t]{2}{*}{ Nitrogen } & \multicolumn{3}{|c|}{$(1 s)^{2}(2 s)^{2}(2 p)^{3}$} \\
\hline & Core & $\longleftrightarrow\llcorner$ & Valensi \\
\hline \multirow[t]{2}{*}{ Hidrogen } & \multicolumn{3}{|c|}{$(1 s)^{1}$} \\
\hline & \multicolumn{3}{|c|}{ Valensi } \\
\hline
\end{tabular}

Batas radius optimum orbital core untuk mendapatkan orbital valensi sebagai basis set plane wave dari atom $\mathrm{Ca}, \mathrm{B}, \mathrm{N}$, dan $\mathrm{H}$ masing-masing sebesar 2,9; 1,2; 0,9; dan 0,55Bohr. Penggunaan orbital luar (valensi) akan meringankan proses perhitungan komputasi, dan menghemat waktu untuk simulasi.

\section{Studi Konvergensi Terhadap Energi Kinetik Cutoff}

Studi konvergensi energi kinetik merupakan cara untuk mengetahui basis set (fungsi gelombang) telah memenuhi kriteria baik dalam memodelkan sistem, yang berarti dengan studi ini bertujuan mencari energi ground-state terendah sistem dengan parameter energi kinetik. Energi kinetik cutoff merupakan batas perbedaan energi total sistem $\left(E_{\text {tot }}\right)$ hasil iterasi perhitungan hingga didapat perbedaan energi sistem satu dengan berikutnya sebesar $0,001 \mathrm{Ha}$. 


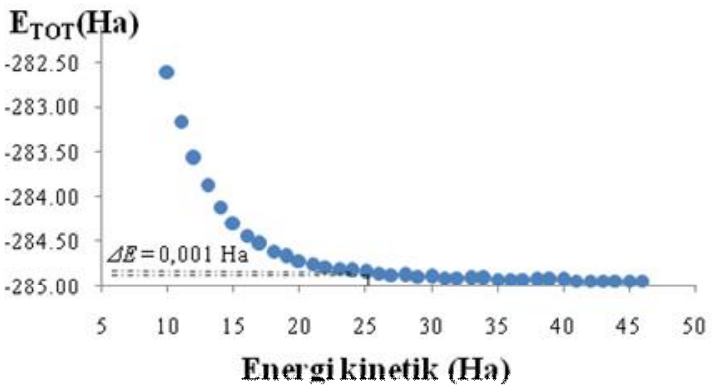

\section{Gambar 1. Struktur kisi kristal $\mathrm{Ca}\left(\mathrm{BH}_{4}\right)_{2} \cdot 2 \mathrm{NH}_{3}$}

Hasil grafik gambar 1 diperoleh selisih energi total sebesar $0,001 \mathrm{Ha}$ terjadi pada energi kinetik sebesar $\pm 25,7$ $\mathrm{Ha}$ atau $700 \mathrm{eV}$, yang berarti dengan energi kinetik sebesar $700 \mathrm{eV}$ telah didapat struktur $\mathrm{Ca}\left(\mathrm{BH}_{4}\right)_{2} \cdot 2 \mathrm{NH}_{3}$ yang teroptimasi.

\section{Studi Struktur dan Elektronik kristal $\mathrm{Ca}\left(\mathrm{BH}_{4}\right)_{2} \cdot 2 \mathrm{NH}_{3}$}

Studi stuktur $\mathrm{Ca}\left(\mathrm{BH}_{4}\right)_{2} \cdot 2 \mathrm{NH}_{3}$ bertujuan mendapatkan model terbaik sesuai dengan eksperimen. Cara yang dilakukan adalah dengan optimasi geometri terhadap strukur yang didapat dari eksperimen menggunakan basis set yang telah dibuat dan parameter optimasi antara lain, energi kinetik cutoff $700 \mathrm{eV}$, skema titik $k$-point $3 \times 3 \times 3$.

Optimasi menggunakan metode $a b$ initio DFT di dalam program ABINIT dan energi perubahan dan korelasi $\left(E_{x c}\right)$ elektron menggunakan pendekatan gradien tergeneralisir (GGA) dari Perdew et al. (1996).

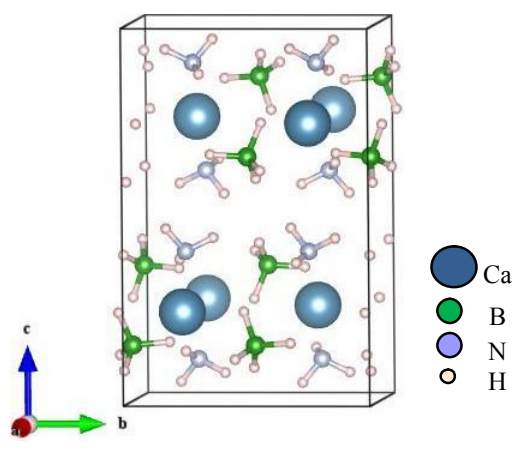

\section{Gambar 2. Struktur kisi kristal $\mathrm{Ca}\left(\mathrm{BH}_{4}\right)_{2} \cdot 2 \mathrm{NH}_{3}$}

Representasi hasil optimasi geometri terhadap kisi kristal $\mathrm{Ca}\left(\mathrm{BH}_{4}\right)_{2} \cdot 2 \mathrm{NH}_{3}$ diperlihatkan dalam Gambar 2 dan 3.

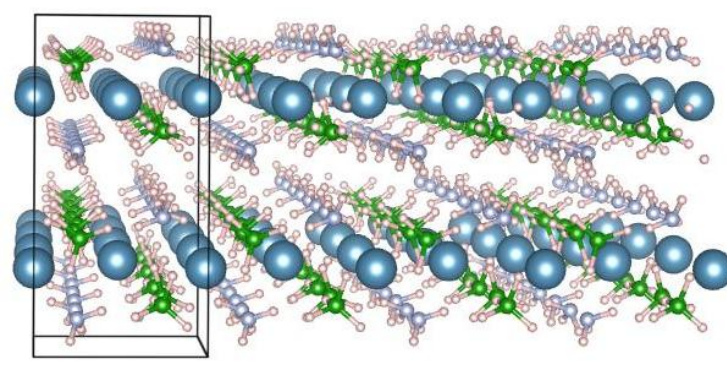

\section{Gambar 3. Struktur 3D kristal $\mathrm{Ca}\left(\mathrm{BH}_{4}\right)_{2} \cdot 2 \mathrm{NH}_{3}$}

Hasil optimasi didapatkan bentuk geometri kristal $\mathrm{Ca}\left(\mathrm{BH}_{4}\right)_{2} \cdot 2 \mathrm{NH}_{3}$ seperti pada Gambar 2, dimana dalam satu kisi kristalnya berisi 76 atom yang tersusun dengan space group ortorombik (Pbcn:60). Perhitungan komputasi menggunakan satu kisi kristal $\mathrm{Ca}\left(\mathrm{BH}_{4}\right)_{2} \cdot 2 \mathrm{NH}_{3} \quad$ dianggap sudah mewakili struktur kristal $\mathrm{Ca}\left(\mathrm{BH}_{4}\right)_{2} \cdot 2 \mathrm{NH}_{3}$ dalam keadaan meruah (bulk) seperti pada Gambar 3 menggunakan teknik 
supercell. Parameter kisi hasil optimasi diperlihatkan pada Tabel 2 .

Optimasi struktur kisi yang

Tabel 2. Parameter kisi hasil kalkulasi vs eksperimen

\begin{tabular}{lll}
\hline Parameter kisi & Kalkulasi & Eksperimen* \\
\hline $\mathrm{a}(\AA)$ & 6,492 & 6,416 \\
$\mathrm{~b}(\AA)$ & 8,317 & 8,390 \\
$\mathrm{c}(\AA)$ & 12,683 & 12,702 \\
Volume $\left(\AA^{3}\right)$ & 684,912679 & 683,751708 \\
$\alpha(\operatorname{deg})$ & 90 & 90 \\
$\beta(\operatorname{deg})$ & 90 & 90 \\
$\gamma(\operatorname{deg})$ & 90 & 90 \\
\hline
\end{tabular}

*Sumber: Chu et al. (2010) disajikan pada Tabel 2 memperlihatkan bahwa setiap parameter kisi menghasilkan data yang tidak jauh berbeda dengan hasil eksperimen, hal ini menjadi poin penting dalam optimasi struktur kristal $\mathrm{Ca}\left(\mathrm{BH}_{4}\right)_{2} \cdot 2 \mathrm{NH}_{3}$ untuk menghasilkan data kisi kristal yang serupa dan dapat dibandingkan dengan eksperimen. Hal ini diperjelas

Tabel 3. Perbandingan koordinat hasil kalkulasi vs eksperimen

\begin{tabular}{|c|c|c|c|c|c|c|}
\hline \multirow[b]{2}{*}{$\mathrm{Ca}$} & \multicolumn{3}{|c|}{ Koordinat kalkulasi (x y z) } & \multicolumn{3}{|c|}{ Koordinat eksperimen $(\mathrm{x} \mathrm{y} \mathrm{z})^{*}$} \\
\hline & 6,134 & 11,669 & 5,992 & 6,062 & 11,831 & 6,000 \\
\hline B & 9,346 & 8,085 & 3,656 & 9,191 & 8,098 & 3,535 \\
\hline $\mathrm{N}$ & 9,216 & 11,514 & 9,629 & 9,247 & 11,651 & 9,473 \\
\hline $\mathrm{H}_{1}(\mathrm{~B})$ & 9,849 & 10,367 & 3,828 & 9,723 & 10,355 & 3,729 \\
\hline $\mathrm{H}_{2}(\mathrm{~B})$ & 7,610 & 7,762 & 2,137 & 7,501 & 7,827 & 1,984 \\
\hline $\mathrm{H}_{3}(\mathrm{~B})$ & 8,690 & 7,273 & 5,752 & 8,503 & 7,259 & 5,592 \\
\hline $\mathrm{H}_{4}(\mathrm{~B})$ & 11,278 & 7,022 & 2,899 & 11,093 & 7,012 & 2,776 \\
\hline $\mathrm{H}_{5}(\mathrm{~N})$ & 8,744 & 10,320 & 11,086 & 8,916 & 10,379 & 10,920 \\
\hline $\mathrm{H}_{6}(\mathrm{~N})$ & 10,959 & 10,916 & 9,013 & 11,019 & 11,209 & 8,773 \\
\hline $\mathrm{H}_{7}(\mathrm{~N})$ & 9,526 & 13,229 & 10,475 & 9,460 & 13,375 & 10,357 \\
\hline
\end{tabular}

dengan geometri struktur posisi atom di dalam kisi yang juga tidak mengalami banyak perubahan seperti yang ditampilkan dalam Tabel 3.

Data hasil optimasi geometri atom-atom ditampilkan sebagai perbandingan koordinat struktur geometri senyawa $\mathrm{Ca}\left(\mathrm{BH}_{4}\right)_{2} \cdot 2 \mathrm{NH}_{3}$ hasil kalkulasi dengan eksperimen seperti pada Tabel 3.
Dalam Tabel 3 menampilkan 10 atom yang menjadi perwakilan dari 76 atom kisi kristal $\mathrm{Ca}\left(\mathrm{BH}_{4}\right)_{2} \cdot 2 \mathrm{NH}_{3}$, dimana koordinat atom dari $\mathrm{Ca}\left(\mathrm{BH}_{4}\right)_{2} \cdot 2 \mathrm{NH}_{3}$ menghasilkan koordinat struktur yang mirip.

Analisis struktur kristal $\mathrm{Ca}\left(\mathrm{BH}_{4}\right)_{2} \cdot 2 \mathrm{NH}_{3}$ dilanjutkan dengan menganalisis bentuk struktural, sifat 
elektronik dan juga sifat dehidrogenasi.

Hal ini dilakukan agar dapat mempelajari hasil pengamatan eksperimen melalui model komputasi.

Analisis struktural, sifat elektronik dan sifat dehidrogenasi kristal $\mathrm{Ca}\left(\mathrm{BH}_{4}\right)_{2} \cdot \mathbf{2} \mathrm{NH}_{3}$

Metode komputasi $A b$ Initio DFT adalah metode yang sangat baik digunakan untuk penentuan struktur dan sifat dari molekul yang bersifat statis atau kurang mengalami perubahan dalam strukturnya (Leach, 2001). Analisis ini memberikan pemahaman mengenai interaksi, panjang ikatan maupun sudut yang terdapat di dalam kristal $\mathrm{Ca}\left(\mathrm{BH}_{4}\right)_{2} \cdot 2 \mathrm{NH}_{3}$.

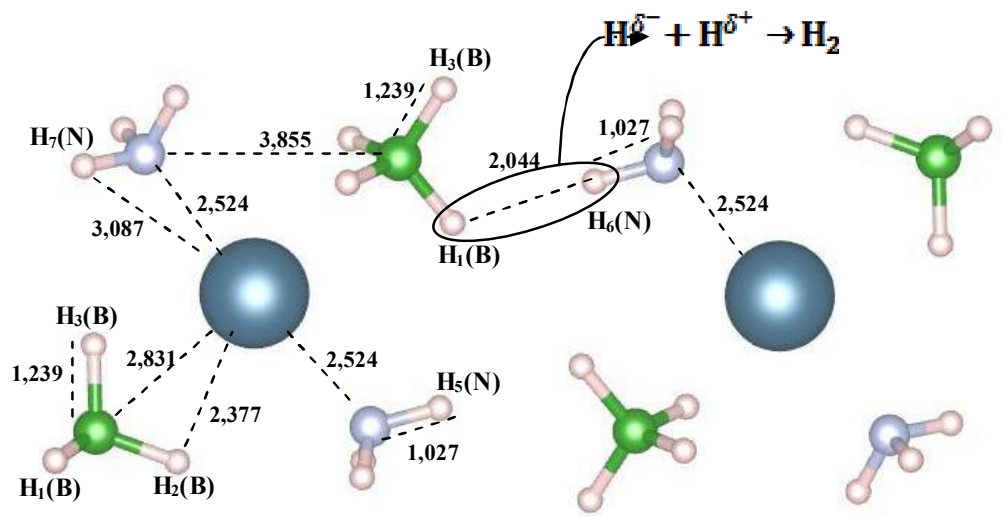

Gambar 4. Panjang ikatan dalam kristal $\mathrm{Ca}\left(\mathrm{BH}_{4}\right)_{2} \cdot 2 \mathrm{NH}_{3}$

\section{- Struktural kristal $\mathrm{Ca}\left(\mathrm{BH}_{4}\right)_{2} \cdot \mathbf{2} \mathbf{N H}_{3}$}

Struktur kompleks sistem

$\mathrm{Ca}\left(\mathrm{BH}_{4}\right)_{2} \cdot 2 \mathrm{NH}_{3}$ berbentuk oktahedral dengan ion $\mathrm{Ca}^{2+}$ sebagai atom pusat yang dikelilingi oleh 4 molekul $\mathrm{BH}_{4}^{-}$pada sisi bidang dan 2 molekul $\mathrm{NH}_{3}$ pada sisi atasbawah. Seperti yang ditampilkan pada Gambar 4.

Pada Gambar 4. diperlihatkan bahwa jarak antara Ca-B sebesar 2,831 $\AA$, mirip dengan $\mathrm{Ca}\left(\mathrm{BH}_{4}\right)\left(\mathrm{d}_{\mathrm{Ca}-\mathrm{B}}=2,88 \AA\right)$ dari penelitian Majzoub dan Rönnebro (2009), mengindikasikan bahwa sistem sistem $\mathrm{Ca}\left(\mathrm{BH}_{4}\right)$. Jarak $\mathrm{Ca}-\mathrm{N}$ sebesar $2,524 \AA$, mirip dengan $\mathrm{Ca}\left(\mathrm{NH}_{2}\right)_{2}\left(\mathrm{~d}_{\mathrm{Ca}-\mathrm{N}}=\right.$ 2,442 - 2,573 $\AA$ ) dari penelitian Senker et al., (1998) mengindikasikan bahwa sistem ini juga mirip dengan sistem $\mathrm{Ca}\left(\mathrm{NH}_{2}\right)_{2}$.

Struktur $\mathrm{BH}_{4}^{-}$dari Gambar 4. memiliki bentuk tetrahedral dengan panjang ikatan $\mathrm{d}_{\mathrm{B}-\mathrm{H}}=1,233 \AA$ dan besar sudut $\mathrm{H}-\mathrm{B}-\mathrm{H}=109,41^{\circ}-110,04^{\circ}$, panjang $\mathrm{B}-\mathrm{H}$ ini sedikit lebih panjang dibanding pada $\mathrm{Ca}\left(\mathrm{BH}_{4}\right)_{2}\left(\mathrm{~d}_{\mathrm{B}-\mathrm{H}}=1,220\right.$ Å) dari penelitian Majzoub dan Rönnebro (2009). Dan untuk molekul $\mathrm{NH}_{3}$ memiliki 
bentuk piramida dengan jarak $\mathrm{d}_{\mathrm{N}-\mathrm{H}}=$ $1,025-1,027 \AA$ dengan sudut $\mathrm{H}-\mathrm{N}-\mathrm{H}$ sebesar $104,81^{\circ}-105,51^{\circ}$, panjang ikatan $\mathrm{N}-\mathrm{H}$ ini lebih panjang dibanding pada fasa gas $\left(\mathrm{d}_{\mathrm{N}-\mathrm{H}}=1,017 \AA\right)$, untuk sudut $\mathrm{H}-$ $\mathrm{N}-\mathrm{H}$ sebesar $104,81^{\circ}-105,51^{\circ}$, besar sudut ini lebih kecil dibandingkan sudut pada fasa gas $\mathrm{NH}_{3}\left(107,80^{\circ}\right)$ (Wells, 1984). Data lengkap disajikan dalam Tabel 4.

Data Tabel 4. memperlihatkan atom $\mathrm{H}$ dari $\mathrm{BH}_{4}^{-}$memiliki jarak lebih dekat dengan atom pusat $\mathrm{Ca}^{2+}$ mengindikasikan atom $\mathrm{H}(\mathrm{B})$ memiliki muatan parsial negatif $\left(\delta^{-}\right)$, sehingga lebih menyukai untuk interaksi dengan atom pusat $\mathrm{Ca}^{2+}$ yang memiliki muatan positif $(+)$.

Tabel 4. Panjang dan sudut ikatan pada kristal $\mathrm{Ca}\left(\mathrm{BH}_{4}\right)_{2} \cdot \mathbf{N H}_{3}$

\begin{tabular}{|c|c|c|c|c|c|c|}
\hline \multicolumn{2}{|c|}{ Atom } & \multirow{2}{*}{$\begin{array}{l}\begin{array}{l}\text { Jarak } \\
(\AA)\end{array} \\
2,831\end{array}$} & \multicolumn{3}{|l|}{ Atom } & \multirow{2}{*}{$\begin{array}{l}\begin{array}{l}\text { Sudut } \\
\left({ }^{\circ}\right)\end{array} \\
110,042\end{array}$} \\
\hline $\mathrm{Ca}$ & B & & $\mathrm{H}_{1}(\mathrm{~B})$ & B & $\mathrm{H}_{2}(\mathrm{~B})$ & \\
\hline $\mathrm{Ca}$ & $\mathrm{N}$ & 2,524 & $\mathrm{H}_{2}(\mathrm{~B})$ & B & $\mathrm{H}_{3}(\mathrm{~B})$ & 109,057 \\
\hline $\mathrm{Ca}$ & $\mathrm{H}(\mathrm{B})$ & $\begin{array}{l}2,377- \\
2,694\end{array}$ & $\mathrm{H}_{3}(\mathrm{~B})$ & B & $\mathrm{H}_{4}(\mathrm{~B})$ & 111,379 \\
\hline $\mathrm{Ca}$ & $\mathrm{H}(\mathrm{N})$ & 3,087 & $\mathrm{H}_{4}(\mathrm{~B})$ & B & $\mathrm{H}_{1}(\mathrm{~B})$ & 108,874 \\
\hline B & $\mathrm{N}$ & $\begin{array}{l}3,645- \\
3,855\end{array}$ & $\mathrm{H}_{5}(\mathrm{~N})$ & $\mathrm{N}$ & $\mathrm{H}_{6}(\mathrm{~N})$ & 105,485 \\
\hline B & $\mathrm{H}_{1}(\mathrm{~B})$ & 1,239 & $\mathrm{H}_{6}(\mathrm{~N})$ & $\mathrm{N}$ & $\mathrm{H}_{7}(\mathrm{~N})$ & 105,517 \\
\hline B & $\mathrm{H}_{2}(\mathrm{~B})$ & 1,232 & $\mathrm{H}_{7}(\mathrm{~N})$ & $\mathrm{N}$ & $\mathrm{H}_{5}(\mathrm{~N})$ & 104,817 \\
\hline B & $\mathrm{H}_{3}(\mathrm{~B})$ & 1,239 & $\mathrm{~N}$ & $\mathrm{Ca}$ & B & 91,910 \\
\hline B & $\mathrm{H}_{4}(\mathrm{~B})$ & 1,233 & B & $\mathrm{Ca}$ & $\mathrm{B}^{\prime}$ & 90,904 \\
\hline $\mathrm{N}$ & $\mathrm{H}_{5}(\mathrm{~N})$ & 1,027 & $\mathrm{~N}$ & $\mathrm{Ca}$ & $\mathrm{N}^{\prime}$ & 176,268 \\
\hline $\mathrm{N}$ & $\mathrm{H}_{6}(\mathrm{~N})$ & 1,027 & & & & \\
\hline $\mathrm{N}$ & $\mathrm{H}_{7}(\mathrm{~N})$ & 1,025 & & & & \\
\hline \multicolumn{2}{|c|}{$\mathrm{H}_{1}(\mathrm{~B})-\mathrm{H}_{6}(\mathrm{~N})$} & 2,044 & & & & \\
\hline
\end{tabular}

Jarak ikatan N-H ini lebih panjang dari $\mathrm{NH}_{3}$ pada fasa gas $(1,027: 1,017)$ mengindikasikan adanya interaksi atom $\mathrm{N}$ dengan $\mathrm{Ca}$, dimana struktur $\mathrm{NH}_{3}$ bersifat basa lewis yang mendonorkan pasangan elektron bebas untuk berinteraksi dengan kation $\mathrm{Ca}^{2+}$ yang bersifat asam lewis, sehingga menyebabkan kerapatan elektron pada $\mathrm{N}$ lebih besar dan kerapatan ikatan $\mathrm{N}-\mathrm{H}$ menjadi lebih rendah, dan menyebabkan ikatan N-H menjadi memanjang.

Pada Gambar 4. juga didapatkan interaksi dua atom $\mathrm{H}$ yang saling berdekatan, yakni antara $\mathrm{H}_{6}(\mathrm{~N})$ dengan $\mathrm{H}_{1}(\mathrm{~B})$, data jarak interaksi terdekatnya adalah sebesar 2,044 $\AA$, interaksi ini adalah interaksi dihidrogen antara $\mathrm{H}_{\mathrm{N}}^{\delta+}$ dari molekul $\mathrm{NH}_{3}$ dengan $\mathrm{H}_{\mathrm{B}}^{\delta-}$ dari molekul $\mathrm{BH}_{4}^{-}$yang berpotensi sebagai sumber molekul hidrogen $\left(\mathrm{H}_{2}\right)$. Interaksi antar dua hidrogen ini mirip dengan ikatan hidrogen tapi bedanya dengan ikatan dihidrogen adalah interaksi dimana atom hidrogen biasanya tidak akan saling berdekatan dengan atom hidrogen lainnya dengan jarak lebih kecil dari 2,4 $\AA$, ciri karakteristik ikatan dihidrogen adalah jarak antar atom hidrogen mendekati 1,8 $\AA$ (Custelcean dan Jackson, 2001).

\section{- Sifat elektronik sistem kristal}

\section{$\mathrm{Ca}\left(\mathrm{BH}_{4}\right)_{2} \cdot 2 \mathrm{NH}_{3}$}

Analisis terhadap sifat elektron di dalam sistem dapat memberikan gambaran sifat sistem kimia. Kerapatan 
keadaan orbital atom atau biasa disebut Density of State (DOS), merupakan analisis terhadap jumlah keberadaan per interval energi dari setiap level energi yang dapat terisi oleh elektron (Atkins, 2006).

Analisis DOS digunakan untuk menganalisis keterlibatan ikatan kimia antar spesies kimia dari sistem kristal $\mathrm{Ca}\left(\mathrm{BH}_{4}\right)_{2} \cdot 2 \mathrm{NH}_{3}$. DOS memiliki bentuk besar intensitas total kerapatan $(\mathrm{eV})$ dari tiap orbital atom berbanding besar energi (eV) dari orbital seperti pada Gambar 5.

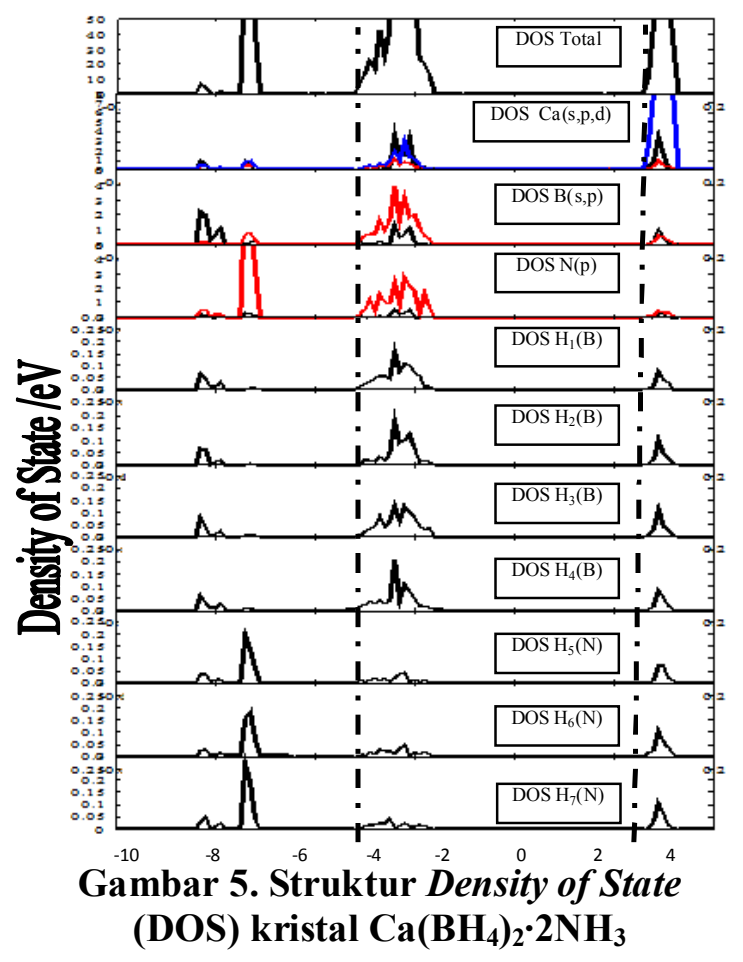

Data DOS kristal $\mathrm{Ca}\left(\mathrm{BH}_{4}\right)_{2} \cdot 2 \mathrm{NH}_{3}$ terbagi menjadi 3 daerah, daerah 1 merupakan daerah DOS pita valensi dengan energi rendah yakni dibawah 4,35 eV, daerah 2 merupakan daerah DOS pita valensi energi tinggi $(-4,35 \mathrm{eV}$ sampai $-2,17 \mathrm{eV}$ ) dan daerah 3 adalah DOS pita konduksi $(3,51 \mathrm{eV})$.

Daerah 1 di sekitar -8,70 sampai 7,89 eV merupakan kontribusi dari kerapatan orbital $s$ atom $\mathrm{B}$ dan $\mathrm{H}$ dari molekul $\mathrm{BH}_{4}^{-}$yang menandakan adanya interaksi kuat hibridisasi orbital $s p$ dari B-H dan di atas -7,48 eV sampai -6,93 $\mathrm{eV}$ merupakan kontribusi dari orbital $p$ atom $\mathrm{N}$ dan $s$ dari atom $\mathrm{H}$ dari molekul $\mathrm{NH}_{3}$ yang mengindikasikan adanya interaksi kovalen hibridisasi orbital $s p$ yang kuat antara $\mathrm{N}$ dan $\mathrm{H}$.

Daerah 2 di sekitar $-4,35 \mathrm{eV}$ sampai -2,17 eV merupakan dominasi kontribusi orbital $p$ atom $\mathrm{B}$ dan $s$ atom $\mathrm{H}$ dari molekul $\mathrm{BH}_{4}^{-}$, ditambah kontribusi yang kecil dari orbital $p$ dari atom $\mathrm{N}$, serta kontribusi kecil orbital $s$ dan $p$ dari atom Ca. Daerah pita valensi (daerah 1 dan 2) ini memperlihatkan DOS dari orbital hibridisasi kombinasi dari orbital s-B, p-B dan s-H yang membentuk orbital hibrid sp3, sedangkan kebutuhan 1 elektron yang digunakan untuk membentuk $s p 3$ diperoleh dari atom $\mathrm{Ca}$ terdekat, hal inilah yang memberikan alasan tentang arah kecendrungan atom $\mathrm{H}$ pada $\mathrm{BH}_{4}^{-}$yang lebih dekat dengan atom Ca dibanding B. Dan daerah 3 di atas 3,51 eV merupakan pita konduksi dari orbital $d$ atom $\mathrm{Ca}$. Atom $\mathrm{B}$ dan $\mathrm{N}$ 
memberikan kontribusi kecil terhadap

Dalam grafik DOS pada daerah pita valensi paling rendah di sekitar $-7,89$ eV yang merupakan kontribusi DOS atom $\mathrm{H}(\mathrm{B})$ dari molekul $\mathrm{BH}_{4}^{-}$dan sangat berdekatan dengan DOS atom $\mathrm{H}(\mathrm{N})$ dari molekul $\mathrm{NH}_{3}$ di daerah 7,48 eV, menguatkan indikasi interaksi ikatan dihidrogen dapat terjadi dari atom $\mathrm{H}(\mathrm{B})$ pada molekul $\mathrm{BH}_{4}^{-}$dan $\mathrm{H}(\mathrm{N})$ pada molekul $\mathrm{NH}_{3}$. Hal ini dikuatkan dengan pita konduksi.

analisis struktur pita elektron dari kristal $\mathrm{Ca}\left(\mathrm{BH}_{4}\right)_{2} \cdot 2 \mathrm{NH}_{3}$ yang diperlihatkan dalam grafik pita energi pada Gambar 6.

Pada Gambar 6. memperlihatkan wilayah pita elektron $\mathrm{H}(\mathrm{B})$ dan $\mathrm{H}(\mathrm{N})$ yang berdekatan dan sangat memungkinkan untuk saling berinteraksi satu sama lain dengan proses eksitasi. Terjadinya eksitasi membutuhkan energi eksternal, sehingga tidak aneh bila sistem

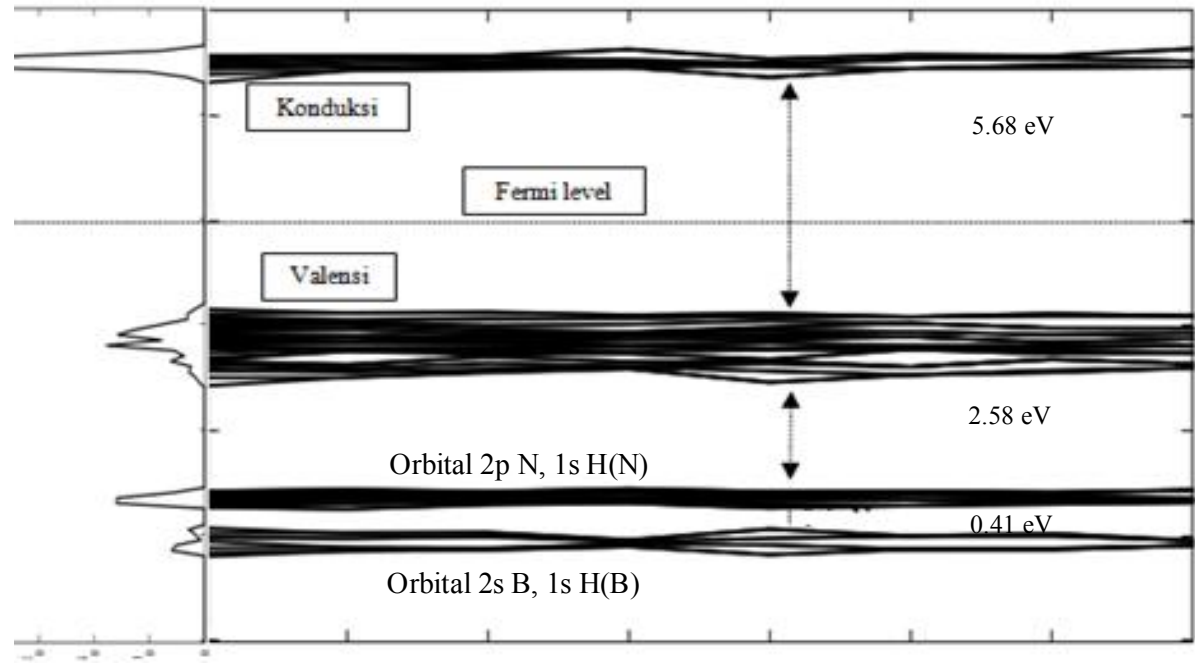

Gambar 6. Struktur pita elektron kristal $\mathrm{Ca}\left(\mathrm{BH}_{4}\right)_{2} \cdot \mathbf{2} \mathrm{NH}_{3}$

ini membutuhkan energi panas eksternal untuk terjadinya proses dekomposisi dan dehidrogenasi.

Pita elektron valensi energi rendah di sekitar $-7,89 \mathrm{eV}$ merupakan kontribusi pita elektron atom $\mathrm{H}(\mathrm{B})$ dari molekul $\mathrm{BH}_{4}^{-}$dan sangat berdekatan dengan pita elektron atom $\mathrm{H}(\mathrm{N})$ dari molekul $\mathrm{NH}_{3}$ di daerah 7,48 eV, selisih celah energinya sekitar $0,41 \mathrm{eV}$, dekatnya celah ini menguatkan indikasi interaksi elektronik dapat terjadi dari ikatan dihidrogen pada atom $\mathrm{H}(\mathrm{B})$ dan $\mathrm{H}(\mathrm{N})$.

Sejauh penelitian ini dilakukan belum ada hasil penelitian eksperimen tentang besar dari nilai celah pita energi band gap dari kristal $\mathrm{Ca}\left(\mathrm{BH}_{4}\right)_{2} \cdot 2 \mathrm{NH}_{3}$, namun dengan membandingkan dengan

Studi Komputasi Metode $A b$ Initio Dft Dalam Kajian Struktural dan Sifat Elektronik

Senyawa Kalsium Borohidrid-Diamonia Sebagai Penyimpan Hidrogen

(Muhammad Arsyik Kurniawan) 
hasil secara teoritis dari penelitian lain seperti pada Tabel 5. maka dapat terlihat bahwa kristal ini memiliki celah pita energi yang besar $(5,68 \mathrm{eV})$ yang mengindikasikan bahwa sistem ini merupakan kristal non-metal dan bersifat insulator.

Tabel 5. Perbandingan besar band gap

\begin{tabular}{cccc}
\hline & XC & Metode & $\mathrm{E}_{\text {gap }}(\mathrm{eV})$ \\
\hline Yuan et al. (2012) & GGA & PAW & 5,6 \\
Zhang et al. (2012) & GGA & PAW & 5,8 \\
Chen danYu (2012) & GGA & PAW & 6,0 \\
Penelitian ini & GGA & PAW & 5,68 \\
\hline
\end{tabular}

Bentuk pola pita elektron kristal $\mathrm{Ca}\left(\mathrm{BH}_{4}\right)_{2} \cdot 2 \mathrm{NH}_{3} \quad$ (Gambar 6) yang berbentuk flat menggambarkan sistem yang cenderung ionik (Ashcroft dan Mermin, 1976).

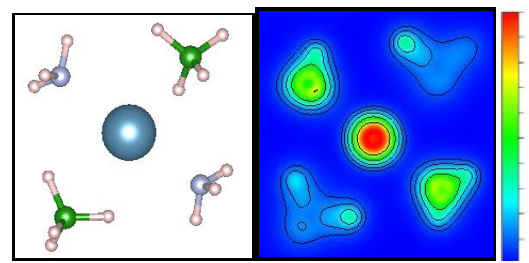

\section{Gambar 7. Distribusi kerapatan elektron}

Pada Gambar 7. memperlihatkan

bahwa kerapatan potensial atom $\mathrm{Ca}$ paling besar. Pada molekul $\mathrm{BH}_{4}^{-}$ distribusi elektron lebih besar pada atom $\mathrm{H}(\mathrm{B})$ daripada atom $\mathrm{B}$, mengindikasikan muatan $\mathrm{H}(\mathrm{B})$ lebih cenderung parsial negatif $\left(\delta^{-}\right)$sedangkan pada atom $\mathrm{B}$ sebagai parsial positifnya $\left(\delta^{+}\right)$.
Distribusi kerapatan elektron pada molekul $\mathrm{NH}_{3}$ menunjukkan kerapatan yang besar pada di sekitar atom $\mathrm{N}$ tapi tidak pada atom $\mathrm{H}(\mathrm{N})$, mengindikasikan muatan $\mathrm{N}$ lebih parsial negatif $\left(\delta^{-}\right)$ sedangkan pada atom $\mathrm{H}(\mathrm{N})$ sebagai parsial positifnya $\left(\delta^{+}\right)$. Posisi atom $\mathrm{N}$ dan $\mathrm{H}(\mathrm{B})$ yang mengarah ke atom $\mathrm{Ca}$ mengindikasikan interaksi muatan negatif dari $\mathrm{N}$ dan $\mathrm{H}(\mathrm{B})$ dengan $\mathrm{Ca}$ yang memiliki potensial inti positif $\left(\delta^{+}\right)$dan interaksi yang terjadi juga akibat distorsi yang diberikan oleh orbital $d$ atom $\mathrm{Ca}$.

Muatan negatif yang dimiliki H(B) merupakan kontribusi ionik dari $\mathrm{Ca}^{2+}$, hal ini terlihat dari muatan $\mathrm{Ca}$ yang mengalami penurunan menjadi $+1,53$. Kejelasan besarnya nilai kerapatan tiap spesies ditampilkan dalam Tabel 6 .

Pada Tabel 6. memperlihatkan distribusi kerapatan elektron lebih dominan terdapat pada atom $\mathrm{H}(\mathrm{B})$ dibandingkan atom B pada molekul $\mathrm{BH}_{4}^{-}$, sehingga memberikan gambaran bahwa atom $\mathrm{H}(\mathrm{B})$ lebih bermuatan negatif $\left(\delta^{-}\right)$dibanding atom B.

Tabel 6. Nilai kerapatan elektron dan muatan atom

\begin{tabular}{lcc}
\hline Elemen & $\rho$ & Muatan atom \\
\hline $\mathrm{Ca}$ & 0,8154 & $+1,53$ \\
$\mathrm{~B}$ & 0,1094 & $+1,80$ \\
$\mathrm{H}(\mathrm{B})$ & 0,3125 & $-0,70$ \\
$\mathrm{~N}$ & 0,4972 & $-1,05$ \\
$\mathrm{H}(\mathrm{N})$ & 0,3414 & $+0,35$ \\
Pair e- N & 0,5995 & \\
\hline
\end{tabular}

Studi Komputasi Metode Ab Initio Dft Dalam Kajian Struktural dan Sifat Elektronik Senyawa Kalsium Borohidrid-Diamonia Sebagai Penyimpan Hidrogen 
Berbeda dengan molekul $\mathrm{NH}_{3}$ dimana kerapatan elektron atom $\mathrm{N}$ lebih besar $\left(\delta^{-}\right)$dibandingkan pada atom $\mathrm{H}(\mathrm{N})$, terutama lebih dominan pada pasangan elektron bebasnya, sehingga atom $\mathrm{H}(\mathrm{N})$ lebih bermuatan positif $\left(\delta^{+}\right)$. Hal ini akan mendukung adanya interaksi dari $\mathrm{H}(\mathrm{B})$ dan $\mathrm{H}(\mathrm{N})$ sebagai interaksi dihidrogen karena masing-masing memiliki muatan parsial yang berbeda.

\section{- Sifat dehidrogenasi $\mathrm{Ca}\left(\mathrm{BH}_{4}\right)_{2} \cdot \mathbf{2 N H}_{3}$}

Dengan maksud mempelajari lebih lanjut sifat dehidrogenasi maupun dekomposisi material $\mathrm{Ca}\left(\mathrm{BH}_{4}\right)_{2} \cdot 2 \mathrm{NH}_{3}$. Perhitungan energi ikat hidrogen $(\Delta \mathrm{E})$ dilakukan dengan persamaan 3 terhadap hidrogen yang teridentifikasi ikatan dihidrogen seperti pada Gambar 4.

$\Delta E_{2}=E_{\text {total }-n: 1}+\frac{n}{2} E\left(\mathrm{H}_{2}\right)-E_{\text {total }}$

dimana $E_{\text {total } 1}$ adalah energi total kristal $\mathrm{Ca}\left(\mathrm{BH}_{4}\right)_{2} \cdot 2 \mathrm{NH}_{3}, \quad E\left(\mathrm{H}_{2}\right)$ adalah energi molekul $\mathrm{H}_{2}$ yang terisolasi, $E_{\text {toral }-n \mathrm{H}}$ adalah energi total kristal $\mathrm{Ca}\left(\mathrm{BH}_{4}\right)_{2} \cdot 2 \mathrm{NH}_{3}$ setelah atom $\mathrm{H}$ terlepas, dan $n$ menyatakan jumlah atom hidrogen yang terlepas.

Data Tabel 7 memperlihatkan bahwa energi ikat $\mathrm{H}(\mathrm{B})$ lebih rendah dibandingkan energi ikat $\mathrm{H}(\mathrm{N}) \quad(2,363$ : 3,429) yang mengidentifikasikan bahwa hidrogen dari atom boron lebih diprioritaskan untuk terjadi disosiasi terlebih dahulu dibandingkan hidrogen dari nitrogen.

Tabel 7. Perbandingan energi ikat hidrogen

\begin{tabular}{lc}
\hline Posisi atom & $\Delta \mathrm{E}_{1}(\mathrm{eV})$ \\
\hline $\mathrm{H}-\mathrm{B}$ & 2,363 \\
$\mathrm{H}-\mathrm{N}$ & 3,429 \\
$\mathrm{H}-\mathrm{B} \& \mathrm{H}-\mathrm{N}(2 \mathrm{H})$ & 2,304 \\
$\mathrm{Ca}\left(\mathrm{BH}_{4}\right)_{2} \cdot \mathrm{NH}_{3}-\mathrm{NH}_{3}$ & 1,516 \\
\hline
\end{tabular}

Studi dekomposisi material dengan pelepasan molekul $\mathrm{NH}_{3}$ dilakukan untuk mempelajari interaksi $\mathrm{NH}_{3}$ dengan material $\mathrm{Ca}\left(\mathrm{BH}_{4}\right)_{2} \cdot 2 \mathrm{NH}_{3}$. Energi pelepasan molekul $\mathrm{NH}_{3}$, sebagai energi ikat $\mathrm{NH}_{3}$ terhadap kristal $\mathrm{Ca}\left(\mathrm{BH}_{4}\right)_{2} \cdot 2 \mathrm{NH}_{3}$ didapatkan sebesar 1,516 eV. Hal ini menunjukkan energi ikat $\mathrm{NH}_{3}$ yang lebih rendah dibanding energi ikat $2 \mathrm{H}$, disini dapat disimpulkan bahwa pelepasan dua hidrogen menjadi $\mathrm{H}_{2}$ kurang dominan dibandingkan $\quad \mathrm{NH}_{3} . \quad$ Fenomena dekomposisi hasil perhitungan ini didapat dan sesuai dengan fakta eksperimental seperti yang telah dilakukan oleh Chu et al., (2010)

\section{Kesimpulan.}

Model senyawa $\mathrm{Ca}\left(\mathrm{BH}_{4}\right)_{2} \cdot 2 \mathrm{NH}_{3}$ terbaik telah berhasil didapat dengan menggunakan tehnik Projector Augmented-Wave (PAW) dari metode Density Functional Theory (DFT) yang merupakan tehnik yang lebih cocok untuk material zat padat. Hasil model yang 
mirip dengan eksperimen dapat digunakan untuk mempelajari bentuk struktur dan sifat elektronik senyawa $\mathrm{Ca}\left(\mathrm{BH}_{4}\right)_{2} \cdot 2 \mathrm{NH}_{3}$, termasuk menjelaskan sifat penyimpanan hidrogen didalamnya.

\section{Pustaka}

Anonim, 2007. Hydrogen Storage Materials. Mater. Matters 2, 3-7.

Ashcroft, N.W., Mermin, N.D., 1976. Solid state physics. Harcourt College Publishers, New York; London.

Atkins, P.W., 2006. Atkins' Physical chemistry, 8th ed. ed. Oxford University Press, Oxford; New York.

Baitalow, F., Baumann, J., Wolf, G., Jaenicke-Rößler, K., Leitner, G., 2002. Thermal decomposition of $\mathrm{B}-\mathrm{N}-\mathrm{H}$ compounds investigated by using combined thermoanalytical methods. Thermochim. Acta 391, 159-168. doi:10.1016/S00406031(02)00173-9

Blöchl, P.E., 1994. Projector augmentedwave method. Phys. Rev. B 50, 17953-17979.

doi:10.1103/PhysRevB.50.17953

Chen, X., Yu, X., 2012. Electronic Structure and Initial Dehydrogenation Mechanism of $\mathrm{M}(\mathrm{BH} 4) 2 \cdot 2 \mathrm{NH} 3 \quad(\mathrm{M}=\mathrm{Mg}, \mathrm{Ca}$, and $\mathrm{Zn}$ ): $\mathrm{A}$ First-Principles Investigation. J. Phys. Chem. C 116 , 11900-11906. doi:10.1021/jp301986k

Chua, Y.S., Wu, G., Xiong, Z., He, T., Chen, P., 2009. Calcium Amidoborane AmmoniateSynthesis, Structure, and
Hydrogen Storage Properties. Chem. Mater. 21, 4899-4904. doi:10.1021/cm9020222

Chu, H., Wu, G., Xiong, Z., Guo, J., He, T., Chen, P., 2010. Structure and Hydrogen Storage Properties of Calcium Borohydride Diammoniate. Chem. Mater. 22, 6021-6028. doi:10.1021/cm1023234

Custelcean, R., Jackson, J.E., 2001. Dihydrogen Bonding: Structures, Energetics, and Dynamics. Chem. Rev. 101, 1963-1980. doi:10.1021/cr000021b

Frueh, S., Kellett, R., Mallery, C., Molter, T., Willis, W.S., King'ondu, C., Suib, S.L., 2011. Pyrolytic Decomposition of Ammonia Borane to Boron Nitride. Inorg. Chem. 50, 783792. doi:10.1021/ic101020k

Gonze, X., Amadon, B., Anglade, P.-M., Beuken, J.-M., Bottin, F., Boulanger, P., Bruneval, F., Caliste, D., Caracas, R., Côté, M., Deutsch, T., Genovese, L., Ghosez, P., Giantomassi, M., Goedecker, S., Hamann, D.R., Hermet, P., Jollet, F., Jomard, G., Leroux, S., Mancini, M., Mazevet, S., Oliveira, M.J.T., Onida, G., Pouillon, Y., Rangel, T., Rignanese, G.-M., Sangalli, D., Shaltaf, R., Torrent, M., Verstraete, M.J., Zerah, G., Zwanziger, J.W., 2009. ABINIT: First-principles approach to material and nanosystem properties. Comput. Phys. Commun. 180, 2582-2615. doi:10.1016/j.cpc.2009.07.007

Hohenberg, P., Kohn, W., 1964. Inhomogeneous Electron Gas. Phys. Rev. 136, B864-B871. doi:10.1103/PhysRev.136.B864

Studi Komputasi Metode Ab Initio Dft Dalam Kajian Struktural dan Sifat Elektronik

Senyawa Kalsium Borohidrid-Diamonia Sebagai Penyimpan Hidrogen

(Muhammad Arsyik Kurniawan) 
Holzwarth, N.A.W., Tackett, A.R., Matthews, G.E., 2001. A Projector Augmented Wave (PAW) code for electronic structure calculations, Part I: atompaw for generating atomcentered functions. Comput. Phys. Commun. 135, 329-347. doi:10.1016/S00104655(00)00244-7

Irani, R.S., 2002. Hydrogen storage: high-pressure gas contaiment 27 , 680-684.

Kohn, W., Sham, L.J., 1965. SelfConsistent Equations Including Exchange and Correlation Effects. Phys. Rev. 140, A1133-A1138. doi:10.1103/PhysRev.140.A1133

Leach, A.R., 2001. Molecular modelling: principles and applications. Prentice Hall, Harlow [etc.].

Majzoub, E.H., Rönnebro, E., 2009. Crystal Structures of Calcium Borohydride: Theory and Experiment. J. Phys. Chem. C 113, 3352-3358. doi:10.1021/jp8064322

Momma, K., Izumi, F., 2011. VESTA 3 for three-dimensional visualization of crystal, volumetric and morphology data. J. Appl. Crystallogr. 44, 1272 1276.

doi:10.1107/S0021889811038970

Perdew, J.P., Burke, K., Ernzerhof, M., 1996. Generalized Gradient Approximation Made Simple. Phys. Rev. Lett. 77, 3865-3868. doi:10.1103/PhysRevLett.77.3865

Senker, J., Jacobs, H., Müller, M., Press, W., Müller, P., Mayer, H.M.,
Ibberson, R.M., 1998. Reorientational Dynamics of Amide Ions in Isotypic Phases of Strontium and Calcium Amide. 1. Neutron Diffraction Experiments. J. Phys. Chem. B 102, 931-940. doi:10.1021/jp972907y

Soloveichik, G., Her, J.-H., Stephens, P.W., Gao, Y., Rijssenbeek, J., Andrus, M., Zhao, J.-C., 2008. Ammine Magnesium Borohydride Complex as a New Material for Hydrogen Storage: Structure and Properties of $\mathrm{Mg}(\mathrm{BH} 4) 2 \cdot 2 \mathrm{NH} 3$. Inorg. Chem. 47, 4290-4298. doi:10.1021/ic7023633

Wells, A.F., 1984. Structural inorganic chemistry, 5th ed. ed. Clarendon Press; Oxford University Press, Oxford [Oxfordshire] : New York.

Yuan, P.-F., Wang, F., Sun, Q., Jia, Y., Guo, Z.-X., 2012. Structural, energetic and thermodynamic analyses of $\mathrm{Ca}(\mathrm{BH} 4) 2 \cdot 2 \mathrm{NH} 3$ from first principles calculations. J. Solid State Chem. 185, 206212. doi:10.1016/j.jssc.2011.11.009

Zhang, G., Yang, J., Fu, H., Zheng, J., Li, Y., Li, X., 2012. Structural and electronic properties of the hydrogen storage compound $\mathrm{Ca}(\mathrm{BH} 4) 2 \cdot 2 \mathrm{NH} 3$ from firstprinciples. Comput. Mater. Sci. 54 , 345-349. doi:10.1016/j.commatsci.2011.10. 037 